\title{
Mechanical - Physical Treatment of Used Motor Oil Within a Sustainable Waste Management System
}

\author{
VELJKO N. ĐUKIĆ, Pan-European University, APEIRON, Banja Luka, \\ Bosnia and Herzegovina \\ Review paper \\ $U D C: 665.765$
}

\begin{abstract}
Waste oils are all mineral or synthetic oils that cannot be used for the purpose for which they were originally produced. These are: hydraulic oils, motor oils, ship oils, liquids for the transfer of heat or insulation, oily remains from reservoirs, oil-water emulsions and various oil-water mixtures. In its chemical makeup used motor oil contains hydrocarbons, organic minerals, heavy metals (cobalt, magnesium, iron, zinc), sulfur, chlorine, nitrogen, phosphorus, compounds from additives and other products that are dangerous as they have cancerous effects on health.

As it is considered the biggest contaminant of the environment and classified as hazardous waste; special attention must be given in the handling of used motor oil to ensure its appropriate disposal.

Setting up of a viable system for Mechanical-Physical Treatment of used motor oil makes it possible to re-use it as a secondary raw material i.e. the problem of collection, transportation, treatment and storing of the used motor oil is being solved.

The subject of this research is the advantage of the mechanical-physical treatment of used motor oil. Rerefined motor oil can be used for multiple purposes such as a base for the other synthetic oils, for heating etc.

Improper disposal of used motor oil causes multiple damage; firstly, losing the valuable secondary base which, with the addition of certain additives, can be used as the basis for the other synthetic oils; secondly, causing damage to the environment by the pollution with inability to repair the damage to all environmental components.
\end{abstract}

Key words: motor oils, mechanical-physical treatment

\section{INTRODUCTION}

When we say that waste is a relative concept or idea, we are referring to something that represents a burden to someone or is considered unusable by one; but for somebody else it could be a useful commodity or material. Our attitude towards the waste itself is important in determining if something is waste or not. Actually, waste means anything that remains after the production of a certain product that has lost its original characteristics and therefore cannot be used as an original product but with additional treatment, stabilization or upgrade can be used for other purposes in order to get some other secondary product[1].

"Waste oils are all mineral, synthetic oils that cannot be used for the purpose for which they were or-

Author's address: Veljko Đukić, Pan-European University, APEIRON, Banja Luka, Pere Krece 13, Bosnia and Herzegovina

Paper received: 02.02.2015.

Paper accepted: 21.04.2015. iginally produced. Those are hydraulic, motor, turbine oils, ship oils or liquids for the heat transfer or insulation, oily remains from reservoirs, oil-water mixtures and emulsions"[2].

Motor oils are produced for the internal engine combustion. Therefore, all motor or passenger vehicles such as cars, buses, mopeds, snowmobiles, boats, lawn mowers, equipment used in agriculture, trains, static machines use motor lube oil. Since most of these machines/motor vehicles are being used in everyday life, the use of motor oil is necessary for the maintenance of the engine and the parts of the engine.

In its chemical make up used motor oil contains hydrocarbons, heavy metals and organic minerals (cobalt, magnesium, iron and zinc) sulphur, nitrogen, chlorine, phosphorus, compounds from the additives and other products which have cancerous effects on health [3]. They are considered as the biggest contaminants for the environment so the special attention must be paid to the handling of the waste motor oils to ensure its appropriate disposal. 
According to The Environmental Protection Agency (EPA) the one drop of used motor oil can contaminate $1 \mathrm{~cm}^{3}$ of the water. From this, we can conclude that disposal or effluence of waste motor oil into the environment can lead to the greater scale pollution. At the surface of the water, motor oil blocks sunrays and oxygen which can result in the death of the fish and the water vegetation. On the soil, it changes micro floras, affecting fertility, endangering the growth and causes metabolic plant disruption.

Incineration in the stoves with inadequate burning plate/firebox, results in the emission of the poisonous gases ( NOx, COx, SOx) into the atmosphere affecting the air quality.

Studies done by the WHO (called The WHO Report) on the effect on human health which determined that: on the skin it causes appearance of benign and malign illnesses, occurrence of papilloma and tumors. Inhaling gases after the combustion of the motor oils shall result in permanent and acute lung condition, lung cancer and prostate cancer.

But, as everything else, it has its positive side, too. The used motor oil, if treated in an appropriate manner, represents valuable resource. It can be used as a base for new synthetic base oils or as fuel for heating. Rerefined secondary oils have weaker oil characteristics than the original oil. That is why they are used as the base for synthetic oils, asphalt bitumen, for heating. Therefore, used motor oil can be used again, but before that it has to be prepared i.e. water, oil and sludge (solid particles) must be removed. In the other words, it has to be cleared, re-refined and only then, can be used. It represents valuable secondary raw-material. In this way, the natural resources are preserved and saved, and the used motor oil represents secondary resource able to finance itself. The level of the economic development conditions the level of production of the waste in general but also the production of the used motor oils[4].

By using the treated waste motor oil has its economic effect; using the waste motor oil does not demand for purchase of the new motor oil $(40 \%$ of the new secondary oil can be generated from a tone of the used motor oil - information acquired by the research done in "Tehnosint" Laktasi company.)

In this way, the hierarchy level of the waste management is being followed i.e. by avoiding the generation of the huge amounts of waste oils; reduction in the quantity of the waste motor oil; by recycling, it is being reused; and all is done by the appropriate mechanical-physical treatment of the waste motor oil which means removal of the water, pure oil and sludge. Sludge is being dehydrated, stabilized and disposed of as the solid waste.
There are two types of motor oil treatments: combustion, by burning the waste oil in the stoves construed for combustion, such stoves have filters for impurities; and re-regeneration, which can be either rerefining or re-conditioning.

Assessed annual quantities of generated waste oil in $\mathrm{B} \& \mathrm{H}$ is between 21500 and $23000 \mathrm{~T} / \mathrm{a}$. In respect of the facilities for treatment of the used motor oil, in the Republic of Srpska, there is one installation for mechanical-physical treatment of the motor oil; and, in Oil Refinery Modrica with capacity to re-refine used motor oil is $10000 \mathrm{t} / \mathrm{a}$ but only $10-15 \%$ is being used.

Setting up the viable system of the mechanicalphysical treatment of the used motor oil enables to use waste motor oil as secondary raw- material i.e. the problem of collection, transport, treatment, disposal of the used motor oil is being solved.

\section{EUROPEAN UNION POLICY ON WASTE MANAGEMENT}

EU Policy states development of the measures such as promotion of the clean production, treating the product to remove dangerous waste characteristics; setting up the technical standards which would limit concentration of the certain dangerous materials in products; by promoting re-use of the waste and recycling of the waste; applying economic instruments; analysis of the life cycle of the product; development of the eco-marking system.

The Geological Survey of Ireland, with Jonathan Durham as lecturer, on $12^{\text {th }}$ of May 2011 held the seminar called "The European Union's Waste Management Policy". According to J. Durham, the European Union Policy in the waste management is composed of three elements:

1. Strategy, 2. Legislature, 3.Juidiciary i.e. Courts solving the waste management cases.

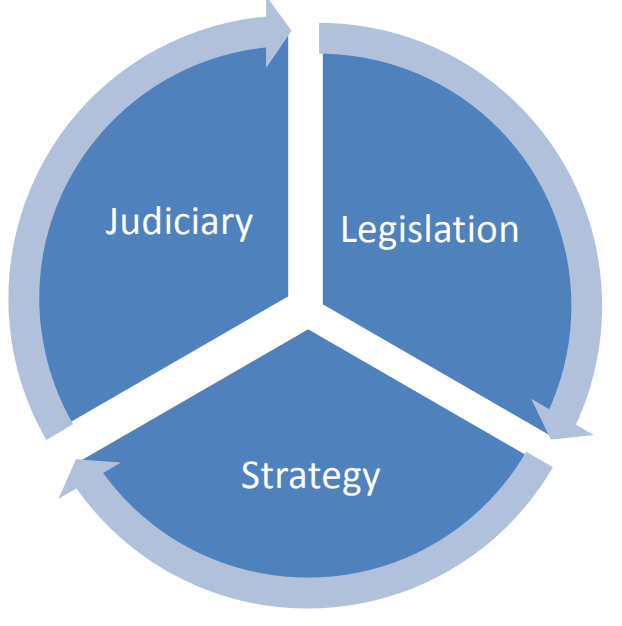

Figure 1 - Symbiotic interaction of the three EU Policy elements [5] 
Under The Strategy, The VI Action Waste Management Plan had been developed. It is the program of activities which has the following priorities: climate change, nature and biodiversity, health and quality of life, natural resources and waste. This program develops the vision to integrate policy on resources, waste and products. It calls on seven theme strategies including the strategy of viable use of natural resources and waste recycling. It has been extended to prevention and recycling.

The Strategy in effect entails viable use of the waste called "Prevention and Recycling Theme Strategy"[6].This Strategy aims to ensure higher level of the environment protection through modernization of the existing legal framework. A long term aim is Europe as recycling society i.e. society trying to avoid production of waste and society using waste as resource. By setting the higher environmental standards internal market will enable activities on recycling and re-use.

Effects of the Strategy:

1. Less waste at the disposal sites

2. More waste materials used for compost

3. More energy from the waste

4. Higher and better recycling

5. Better waste prevention

6. Cleaner environment

\section{SETTING UP THE WASTE ECONOMY}

Waste management economy in Bosnia and Herzegovina is defined as:

„Waste management economy represents the sum of all political, science, mechanical and other measures to achieve waste reduction, use of the waste and safe waste disposal in order to maintain the existing quantity of production and consummation" [7].

\subsection{The importance of establishing the waste economy for the environment}

Not only has progress in the economy and technology in the past few decades significantly endangered the health of people, but also has degraded environment in its basic elements: air, water, soil, flora and fauna. In order to protect eco-system many countries have adopted certain legal framework to ensure proper eco-actions in the countries that are not ecofriendly[8]. Today, waste disposal in the EU countries has been done in the modern dump yards with high degree of security for the environment; but without unlimited power of absorption. Therefore, the amount of waste should be reduced in order to re-use its certain components.

The main task of waste management economy is to use waste generated in the production process, consumption and other actions in order to employ it in the circular flow. Total recycling of the waste is impossible to achieve because the recycling itself generates certain amount of waste. Recycling can be viewed from many different aspects and the load it does to the environment is the most important.

Generally accepted solution of the overall waste management economy system in Europe is known as " $4 \mathrm{R}$ " which means:

1. REDUCTION - reducing or avoiding production of the waste

It is prevention strategy carried out through special policy, application of the regulatory, economic and social tools.

\section{REUSE - Use of waste without treatment}

The procedure of the waste management based on direct re-use of the product for which it was originally made (using the glass waste for the production of the glass products).

3. RECYCLING - recycling of the waste i.e. waste treatment in order to use it's materials or as energy

The waste management procedures are based on the use of the materials from which the product was made, for the same or different purpose.

4. RECOVERY - renewal, reuse for the same purpose after treatment (reusable packaging)

Regenerating as the waste management procedure based on thermal, chemical or physical treatment or biological re-production of materials from which the product was made in order to make new production material i.e. energy that can be directly used. Reusing of the waste saves primary resources (iron ore, copper, aluminum, led) and primary energy (fossil fuels). The disposal of the waste is final procedure in the waste management system and should be used for all other waste that cannot be used again, recycled or regenerated. Although, the full applications of these rules have not yet been achieved, they have become the part of the legal framework in many countries.

The ultimate aim in the waste economy is: "Not using dump disposals anymore i.e. developing non-du$\mathrm{mp}$ disposals in the waste management system, creating dumpless society"[7].

\section{MECHANICAL-PHYSICAL TREATMENT OF USED MOTOR OIL}

\subsection{Concept of mechanical-physical treatment of used motor oil}

Mechanical-physical treatment is a complex process including separation and removal of the impurities found in the used motor oil. It is a process of cleaning and removing solid particles and water from the used motor oil. This treatment prepares used motor oil for re-use. Mechanical-physical treatment is based on 
circulation of oil through the installation and removal of the work medium being done through the rotating container of the separator. The separation of the additives, acids, soluble products from very contaminated oil, and the poor qualities oil; there is a separation of sulphur, non-saturated asphalt compounds, coloured compounds.

Schematic draft of the installation describes process of mechanical-physical treatment of the motor oil (picture 2 and 3.):

1. A specialized vehicle is used for transport waste motor oil from the collection point to the installation. From the specialized vehicle, the used motor oil is being poured into the tank for used motor oil. From tank containing the used motor oil is pumped for the further treatment, into separator.

2. A separator is turned on to achieve $6300-6400$ rotations in a minute. Then, the separator is automatically performing washing and closing for 2-4 minutes. The heaters are turned on at the tank under the separator.

3. Work medium is automatically pumped from the tank for used motor oil through the heater at the separator's base in order to reach work temperature of $85^{\circ} \mathrm{C}$. Work-medium is being pumped and keeps on circulating through electrical-heater. The separation of motor oil and water is being done in the separator.

4. During the separation, work medium is being divided into treated oil and which is being pumped via centripetal pump into the tank number 2- clean oil.

5. The water from the separator goes into the existing reservoir under separator, equipped with minimum - maximum regulator and safety tank with chambers- than, is automatically being pumped and transported into tank number 3 (water and oil).

6. Air compressor, installed on the side, automatically regulates air to open all electro-magnetic valves programmed in the main computer panel.

7. Washing water is in the tank on top and being heated at the temperature of $60^{\circ}-75^{\circ} \mathrm{C}$ via electrical heater of the boiler and directly sent into the valve for the pressure regulation installed at the separator base for automatic shutting/ opening.It is automatic process depending of the temperature on the heater, after which the separator is clean.

Temperature is being checked after the display process:

a. Set temperature of $40^{\circ} \mathrm{C}$ is in the tank under the separator

b. In front of and behind electrical heater temperature should always be $85^{\circ} \mathrm{C}$ at 77 minutes.
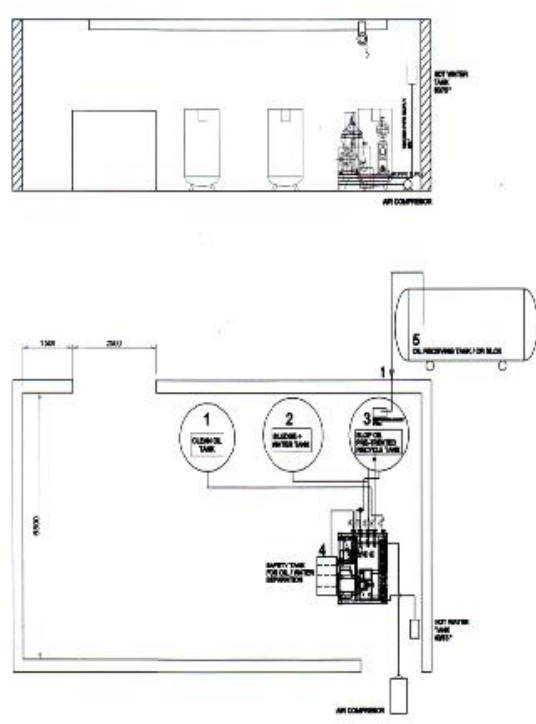

Legend:

1-Clean oil, 2-Water+sludge, 3-Pretreated waste oilrecycle tank, 4-Safety tank-water/oil from the separator, 5 -A receiving tank for the oil/cistern.

\section{Figure 2 - The schematic draft of the installation}

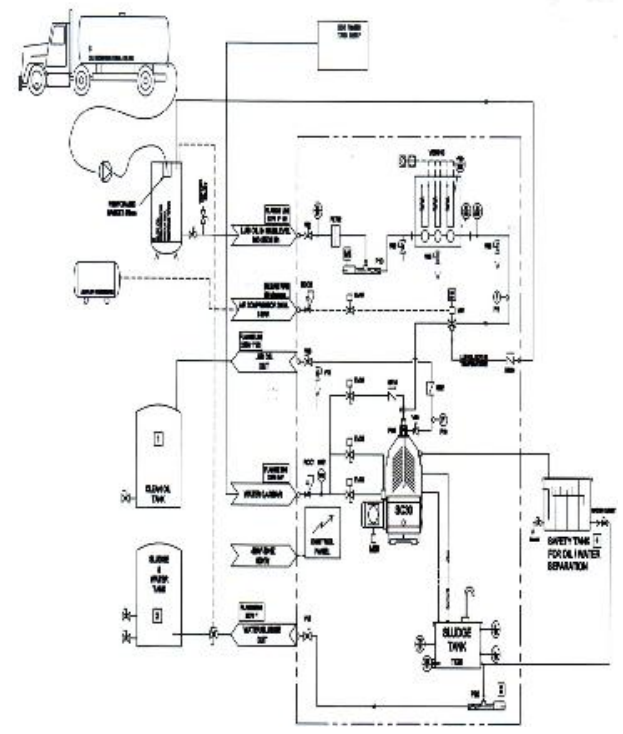

Legend:

1- Clean oil, 2-Water+sludge, 3-Pretreated waste oilrecycle tank, 4-Safety tank-water/oil from the separator, 5-A receiving tank for the oil/cistern.

\section{Figure 3 - Functional scheme}

\section{AIR QUALITY ANALYSIS AFTER \\ INCINERATION OF THE USED MOTOR OIL}

Within the scientific-research work the analysis of the air had been conducted on the location of the installation in order to introduce regular use of mechanical - physical treatment in the centrifugal separator and to protect the air from the pollution. For the air quality monitoring, GASMET DX 4030 portable 
analyzer eight channel air sample taken from the environment and the work location. The appliance is measuring 50 gas components and has a GASMET DX 4030 referring library with 250 components. The concentration of the different components (organic and inorganic) with standard software is connected to a laptop. Universal automatic air sample taker UB-M3/1 is composed of the following elements: the box, eightchannel system enabling the air flow through filter paper and dissolutions ready for the absorption of the certain pollutants[9].

Sulphur dioxide $\left(\mathrm{SO}_{2}\right)$ : acidimetry method used, hydrogen peroxide method. The air being conducted into the hydrogen peroxide in gas chamber, $24 \mathrm{hrs}$, velocity $0,5 \mathrm{~m} / \mathrm{min}$. The sulphur acid is neutralized by titration.

Soot: reflectometry method. The amount is determined measuring the level of the darkness of the spot made as a result of the filtering the air through the white filter paper set on the handle of the paper with the smooth side facing downwards and the air being released $24 \mathrm{hrs}$, with velocity $0,5 \mathrm{lit} / \mathrm{min}$.

Nitrogen dioxide: photo-electric photometry method with ethylenediamine. Nitrogen dioxide reacts with sulfone amides building diazonium compound and altogether creates intensively coloured compound, whose intensity is being determined by photo-electric photometry. The air released into the gas chamber with water solution of triethanolamine to sample nitrogenoxide.

Carbon monoxide: spectrometry method with silver salt and sulfamin-benzoic acid. Contact of air and dissolution of sulfamin-benzoic acid and silver-nitrate builds colloidal silver suspension whose absorption intensity is determined by spectrophotometer.

Ground-level ozone: neutral buffer potassium iodide method. Oxidants react with potassium iodide releasing iodide in buffer solution of potassium-hydrogen sulphates and dinatrium- hydrogen phosphate at $\mathrm{Ph}=6.8$. Absorption of dissolution is measured by spectrometry.

Suspended particles: the concentration of the dust is examined by MICRODUST 880 IS Airsol Monitoring System. Measuring of the dust concentration is achieved by using technique of dispersing sun-lightsusing infrared light projected in the measuring chamber.

The examination results are represented in the tables 1 and 2 .

Table 1. Outside measuring results at location

\begin{tabular}{|l|l|}
\hline Air temperature & $23,6^{\circ} \mathrm{C}$ \\
\hline Relative air humidity & $68,3 \%$ \\
\hline Air flow speed & $0,8 \mathrm{~m} / \mathrm{s}$ \\
\hline Air pressure & $988,0 \mathrm{mbar}$ \\
\hline
\end{tabular}

Tabela 2. The results of the concentration of the pollutants

\begin{tabular}{|l|l|l|l|}
\hline \multicolumn{2}{|l|}{ Measured pollutants } & Sampling period & Quantity \\
\hline $\mathrm{SO} 2$ & $\mu \mathrm{g} / \mathrm{m}^{3}$ & 1 hour & 26 \\
\hline $\mathrm{NO} 2$ & $\mu \mathrm{g} / \mathrm{m}^{3}$ & 1 hour & 19 \\
\hline $\mathrm{CO}$ & $\mu \mathrm{g} / \mathrm{m}^{3}$ & 1 hour & 37 \\
\hline $\mathrm{O} 3$ & $\mu \mathrm{g} / \mathrm{m}^{3}$ & 1 hour & 38 \\
\hline LC 10 & $\mu \mathrm{g} / \mathrm{m}^{3}$ & 1 hour & 14 \\
\hline
\end{tabular}

The results presented in the table 2 shows that concentration of sulphur dioxide, soot, nitrogen dioxide and flying particles in total is below average values. Daily concentration of sulphur dioxide, nitrogen dioxide and flying particles do not exceed average value of the target values in the air. Concentration of sulphur dioxide, nitrogen dioxide in the sampling period of $1 \mathrm{hr}$ is below annual average value and below target values and for the flying particles in the period of 24 hrs. Carbon monoxide and ozone showed high values for the period of eight hours have not exceeded prescribed values.

Comparing the results of measuring of one-hour emission concentration with those prescribed in the Decision on The Air Pollution Protection in Banja Luka Area it is visible that:

1. Average concentration of sulphur dioxide based on the values of emission concentration at the location, determined that the air quality belongs to the first class air quality with minor pollution.

2. Average concentration of the flying particles at the location has placed the air quality in the first class quality (zone with the minor, insignificant pollution).

3. Concentration of the carbon monoxide, based on the emission concentration at the location has placed the air quality into the first air quality class.

4. Based on the one hour concentration of the nitrogen oxide, the air quality is placed into the first class i.e. the minor polluting zone, clean air.

\section{COSTS TO ESTABLISH VIABLE WASTE OIL MANAGEMENT SYSTEM}

Costs to setting the used motor oil management system should cover the cost to determine authorized receiving spots for authorised legal and physical entities, to conduct the collection, authorised legal and physical entities for the processing of the used motor oil and financial investment into the infrastructure treatment of the used motor oil.

Financial planning includes calculation of the cost, capital investment and refund of the cost. By detailed financial analysis the cost should cover expenditures during implementation of the project, find and confirm 
the existence of the financial resources to cover further costs, determine the price level for the refund of the investment and prove the financial viability of the project.

In the assessment of the investment and operation costs as well as potential financial sources, the following should be determined:

The flow of the used motor oil as hazardous waste in order to ensure facility and management system;

- Material capacities necessary to achieve the aims of re-use of the refined motor oil without any danger for the environment;

- Identification of the system, facility and equipment in order to manage these capacities

- Defining the capital investment and operation costs;

- Assessment of the scope to the expected costs;

- Identification of the domestic and foreign investment sources available for this purpose;

- Carry out the assessment to cover resources deficit;

- Identify economic instruments of imbalance between investments costs and sources of financing, as well as conduct the assessment of the instrumental resources necessary as the priority measures.

Analysis should be based on identification of the system, facilities and equipment necessary and carried out in the surrounding countries.

Those obligated to pay the fee would be: manufacturers, i.e. importers of the new mineral and synthetic oil.

The compensation fee would be calculated according to the quantity of the products or imported mineral or synthetic oil or lubricants except or the edible oils and emulsions. The height and the manner of calculation and payment for the waste oil management would be determined in waste oil management in the certain amount as net and salary would be determined when products are firstly put on market.

Funds realised from the collection of waste motor oils shall become a part of the budget, and shall be used in accordance with The Waste Management Law prescribed as "intentional use of funds realised from the compensation for special waste flow-financing of the program, projects and other investment operative activities related to waste management". The Provision on the amount and conditions for allocation of incentive funds related to oil shall be brought pursuant to the Waste Management Law which determines incentive funds for reprocessing, recycling and the use of waist oil as a secondary raw material in a fixed amount per kilogram.

Incentive funds shall be allocated to the investors engaged on the waste oil management in order to:

- Implement the legal framework,

- Establish the organization of the waste oil management,

- Create capacities for waste oil management (private and public sector).

\section{CONCLUSION}

Waste motor oil is a valuable resource. It is classified as the hazardous waste because of its characteristics and dangerous effects on health and the environment. The waste oils and oily waste represent one of the biggest pollutants of the environment. Therefore, the used motor oils are required to be handled in a proper manner. Handling entails correct actions of collection, receiving treatment and disposing of the waste motor oil. Using the motor oil is being ensured through out setting up the legal system, procedures in the collection system through the delivery points, the treatment system in the facilities for the treatment of the used motor oil and which have to meet the requirements in order to protect the environment.

Combustion i.e. co-combustion can use the used motor oil as the fuel. When used for heating, co-combustion must be done in the facilities constructed for such a purpose, with the burning plate/firebox constructed for those purposes and also, that level of the bad emissions of COx, NOx, TFP must not exceed concentration prescribed by the Rulebook on Level of Concentration into the Air in order to avoid pollution of the atmosphere.

The development of the viable system for mechanical-physical treatment of the used motor oil in Republic of Srpska means:

- Prevention and reduction of non-consumption of the used motor oil.

- Re-use and recycling.

- Organizing the collection and transportation.

- Safety disposal of used motor oil.

- Costs to establish the viable management system of the used motor oil.

\section{REFERENCE}

[1] Đukić,V., Osnovi zaštite životne sredine/ The Fundamentals for the Environmental Protection, Panevropski univerzitet Apeiron/ Pan-European University Apeiron, Banja Luка, 2008,pp.121-132.

[2] Minstarstvo zaštite prirode i okoliša RH/ Ministry for the Protection of the Environment and Nature RC, 
Pravilnik o gospodarenju otpadnim uljima/The Rulebook on the Waste Oil Management.

[3] http:www.ehow.com/ waste oils

[4] P. Pavlin, Postupanje sa otpadom, Fond za zaštitu okoliša i energetsku učinkovitost/Handling the Waste, Protection of the environment and energy efficiency, Zagreb,2006,pp.10-13.

[5] http:www.igi.ie

[6] Direktiva Savjeta EU 2008/98/ EC/ EU Council Directive 2008/98/EC.

[7] Sredojević, J., Reciklaža otpada/The Recycling of the Waste, Mašinski fakultet u Zenici, Zenica, 2006.
[8] Ministarstvo poljoprivrede i zaštite životne sredine RS, Pravilnik o uslovima, načinu I procedurama u upravljanju otpadnim uljima u Republici Srbiji, (,Službeni glasnik RS", br.71/2010) Ministry of agriculture and environmental protection of RS, Rulebook on Conditions, Manner and Procedure in Waste Oil Management in Republika Serbia (,Official Gazzette RS“, no.71/ 2010).

[9] Institut zaštite ekologije i informatike Republike Srpske/ Institute of Protection, Ecology and Informatics of the Republic of Srpska, Zapisnik o ispitivanju kvaliteta vazduha, Banja Luka 2012./ Report on the air quality examination, Banja Luka, 2013.

\section{REZIME}

\section{MEHANIČKO-FIZIČKA OBRADA ISTROŠENOG MOTORNOG ULJA U SISTEM ODRŽIVOG UPRAVLJANJA OTPADOM}

Pod otpadnim uljima podrazumijevamo sva mineralna, sintetička ulja neupotrebljiva za svrhu za koju su prvobitno namijenjena, kao što su hidraulična ulja, motorna, turbinska, brodska ulja ili tečnosti za prenos toplote ili izolaciju, uljni ostaci iz rezervoara, mješavina ulje-voda i emulzije. U hemijskom sastavu istrošeno motorno ulje sadrži hidrokarbonate, teške metale i organske minerale (kobalt, magnezijum, željezo, cink) sumpor, azot, hlor, fosfor, jedinjenja iz aditiva, i ostalih produkata koji imaju kancerogena svojstva i opasni su po zdravlje. Smatraju se jednim od najvećih zagađivača životne sredine pa se prilikom postupanja sa otpadnim motornim uljima mora voditi računa o njihovom pravilnom odlaganju. Uspostavljanje održivog sistema mehaničko-fizičke obrade istrošenog motornog ulja omogućava da se istrošeno motorno ulje upotrijebi kao sekundarna sirovina odnosno rješava se problem sakupljanja, transporta, obrade, zbrinjavanja istrošenog motornog ulja. Predmet istraživanja su prednosti mehaničko-fizičke obrade istrošenog motornog ulja. Prerađeno ulje se može koristiti za više namjena kao npr. baza za druga sintetička ulja, kao energent za dobijanje toplotne energije itd. Nesavjesno odlaganje istrošenog motornog ulja uzrokuje višestruke štete: kao prvo gubimo vrijedan sekundarni proizvod koji, uz dodavanje određenih aditiva, može da se koristi kao baza za druga sintetička ulja; kao drugo, uzrokovanjem havarije u komponentama životne sredine, koja se ogleda u njenom zagađenju te nemogućnosti sanacije uzrokovane štete.

Ključne riječi: motorna ulja,mehaničko-fizička obrada,održivo upravljanje 